\title{
Sistem Informasi Geografis Pemetaan Jaringan Irigasi dan Embung di Lombok Tengah
}

\section{Geographical Information System for Mapping of Irrigation Networks and Reservoir in Central Lombok}

Ahmat Adil $^{1}$, Bambang Krismono Triwijoyo

Universitas Bumigora, Indonesia

\begin{tabular}{l} 
Article Info \\
\hline Article history: \\
Received, 18 Maret 2021 \\
Revised, 3 Mei 2021 \\
Accepted, 6 Mei 2021 \\
\hline Kata Kunci: \\
Sistem Informasi Geografis \\
Model spasial \\
Pemetaan \\
Irigasi \\
Embung
\end{tabular}

\section{Keywords:}

Geographical Information System Spatial model

Mapping

Irrigation

Reservoirs

\begin{abstract}
ABSTRAK
Irigasi sebagai alternatif pengairan lahan tadah hujan pada musim kemarau, digunakan untuk meningkatkan produksi hasil pertanian. Pemetaan Jaringan irigasi dan embung pada Kabupaten Lombok Tengah menggunakan sistem data spasial dan non-spasial, yang selama ini masih menggunakan pemetaan secara konvensional. Data Spasial dapat menunjuk posisi geografis dengan setiap karakteristik memiliki satu lokasi yang harus ditentukan dengan cara yang unik. Pemetaan dengan model data spasial, dirancang dengan tahapan seperti analisa kebutuhan perangkat lunak, desain, pembuatan kode program dan pengujian. Metode yang digunakan dalam penelitian ini adalah Analisis spasial, merupakan kumpulan - kumpulan dari teknik yang dapat digunakan untuk melakukan pengolahan data SIG. Hasil dari analisis data spasial sangat bergantung dari lokasi atau tempat di mana objek sedang dianalisis. Manipulasi data, akan menampilkan jendela manipulasi data non-spasial jaringan irigasi, embung, dan kecamatan. Pada jendela manipulasi data, pengguna dapat melakukan penambahan, perubahan dan penghapusan terhadap data tabular yang ada, dan memiliki fasilitas pencarian sesuai dengan data yang sedang diakses.
\end{abstract}

\section{ABSTRACT}

Irrigation as an alternative to irrigating rainfed land in the dry season is used to increase agricultural production. Mapping of irrigation networks and reservoirs in Central Lombok Regency uses spatial and non-spatial data systems, which so far still use conventional mapping. Spatial data can designate geographic positions with each characteristic having one location that must be determined in a unique way. Mapping with a spatial data model is designed with stages such as software requirements analysis, design, programming and testing. The method used in this research is spatial analysis, which is a collection of techniques that can be used to perform GIS data processing. The results of spatial data analysis are highly dependent on the location or place where the object is being analyzed. Data manipulation, will display a nonspatial data manipulation window for irrigation networks, reservoirs, and districts. In the data manipulation window, users can add, change and delete existing tabular data, and have search facilities according to the data being accessed.

This is an open access article under the CC BY-SAlicense.

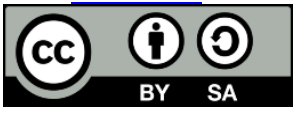

\section{Penulis Korespondensi:}

Ahmat Adil,

Program Studi Ilmu Komputer,

Universitas Bumigora,

Email: ahmat.adil@universitasbumigora.ac.id 


\section{PENDAHULUAN}

Sebagai salah satu alternatif pengairan lahan tadah hujan pada musim kemarau, irigasi sangat membantu meningkatkan produksi hasil pertanian, dengan tidak mengandalkan hujan yang datangnya sering tidak menentu. Irigasi menggunakan sistem berupa saluran dan bangunan tertentu merupakan penyediaan, pengambilan, pembagian, pemberian dan pengaliran [1].

Jaringan irigasi dapat dibedakan ke dalam tiga tingkatan berdasarkan cara pengaturan pengukuran aliran air dan kelengkapan fasilitas[2] yaitu 1) jaringan irigasi sederhana, air akan mengalir ke saluran pembuang dan pembagian air tidak diukur atau tidak diatur, serta persediaan air berlimpah dengan kemiringan berkisar antara sedang sampai curam, 2) semiteknis yaitu dilengkapi dengan bangunan pengambilan dan bangunan pengukur dibagian hilir dengan bendungan terletak di sungai, juga dibangun beberapa bangunan permanen di jaringan saluran air, serta sistem pembagian air jaringan irigasinya sederhana, dan 3) teknis, yaitu jaringan irigasi dan pembuangan/pematus terpisah, yang membuat saluran irigasi dan pembuang tetap bekerja sesuai dengan fungsinya. Saluran irigasi dan saluran pembuang mengalirkan air ke sawah dan air lebih dari sawah ke saluran pembuang alamiah akan diteruskan ke laut [3].

Selain irigasi ada juga embung yang dibangun untuk menampung kelebihan air hujan di musim hujan berupa waduk di lahan pertanian yang berukuran mikro ( small farm reservoir) [4]. Embung sebagai sumber irigasi suplementer untuk budidaya komoditas pertanian bernilai ekonomi tinggi (high added value crops) untuk menampung hujan di musim kemarau atau di saat curah hujan makin jarang. sebagai salah satu teknik pemanenan air (water harvesting), embung sangat sesuai di segala jenis agroekosistem[5][6]. Sesuai pemanfaatanya, embung dapat mendistribusikan dan menjamin ketersediaan pasokan air untuk keperluan tanaman ataupun ternak di musim kemarau dan penghujan[7].

\subsection{Pemetaan}

Proses penyajian informasi muka bumi yang fakta (dunia nyata), termasuk bentuk permukaan bumi dan sumbu alamnya, skala peta, sistem proyeksi peta, serta simbol-simbol dari unsur muka bumi disebut pemetaan [8]. Sementara pemetaan digital atau digital mapping adalah cara dalam pembuatan peta, untuk keperluan pencetakan dan dalam format peta digital. Berikut ini ada beberapa alasan pemetaan data dilakukan antara lain [9]: 1. Menimbulkan daya tarik yang lebih besar terhadap objek yang ditampilkan. 2. Suatu aspek yang penting dapat diperjelas, disederhanakan, dan diterangkan. 3. Pokok-pokok batasan dalam tulisan atau pembicaraan dapat ditonjolkan melalui peta. Sebagai sumber data bagi yang berkepentingan, peta juga dapat dipakai. 4. Untuk memudahkan dalam penyampaian informasi, peta juga berfungsi sebagai alat komunikasi antara membuat peta dengan pengguna.

\subsection{Sistem Informasi Geografis}

Sebagai sesuatu hal yang penting dalam system pengeglolaan data, sistem Informasi geografis (SIG), ditekankan pada pengelolaan data spasial, dan menjadi hal yang penting dalam pengelolaan data Sistem Informasi Geografis. Proses pengolahan dilakukan dengan menerapkan kaidah-kaidah relasional terkait secara simultan. Selain berfungsi untuk memindahkan / mentransformasi peta konvensional (analog) ke bentuk digital (digital map), SIG juga mempunyai kemampuan untuk mengolah dan menganalisis data yang mengacu pada lokasi geografis menjadi informasi berharga[10].

Kemampuan menganalisis sistem seperti analisa statistik dan overlay yang disebut analisa spasial merupakan karakteristik utama SIG, sering digunakan dengan istilah analisa spasial. Berbeda dengan system informasi biasa yang hanya menggunakan data flat, pada SIG menambahkan dimensi 'ruang (space)' atau geografi. Kombinasi ini menggambarkan attribut-attribut pada bermacam fenomena seperti umur seseorang, tipe jalan, dan sebagainya, yang secara bersama dengan informasi seperti dimana seseorang tinggal atau lokasi suatu jalan[11].

Beberapa keistimewaan SIG adalah kemampuan menganalisis seperti analisa overlay dan analisa proximity, dimana analisa proximity merupakan analisa geografis yang berbasis pada jarak antar layer sementara proses integrasi data dari lapisan-lapisan yang berbeda disebut analisa overlay. Dalam analisis spasial, prosesnya dilakukan dengan meng-overlay dua peta yang kemudian menghasilkan peta baru hasil analisis[12].

Pemetaan jaringan irigasi di Lombok tengah yang masih dilakukan secara konvensional (analog), membutuhkan pengembangan teknologi secara digital. Untuk itu pemetaan jaringan irigasi dan embung secara digital dengan memanfaatkan SIG akan menjadi model alternative dalam pemetaan jaringan dan embung. Bidang Pengairan melakukan pembaruan data daerah irigasi dan embung dengan memanipulasi data daerah irigasi dan embung menggunakan aplikasi Arcview atau ArcGIS untuk mengolah data spasial dan Microsoft Excell untuk mengolah data non-spasial

\subsection{Model Data Spasial}

Dalam SIG untuk merepresentasikan objek yang bersifat geografis seperti jalan, sungai, dan sebagainya dapat direpresentasikan kedalam bentuk data spasial. Data spasial memiliki sistem koordinat tertentu sebagai dasar referensinya dan memiliki informasi lokasi (spasial) dan informasi deskripsif (nonspasial)[11]. Dalam SIG untuk merepresentasikan data spasial dapat menggunakan 2 format, yaitu 1) model data raster yaitu model data yang menampilkan, menempatkan, dan menyimpan data spasial menggunakan struktur matriks atau piksel-piksel yang membentuk grid[11]. Model data raster ditandai dengan nilai-nilai (bilangan) elemen matriks untuk merepresentasikan suatu objek. Contoh data spasial dalam model raster adalah citra 
satelit, citra radar, dan gambar digital lainnya.dan model data vektor. 2) Model Data Raster yaitu Model data vektor menampilkan, menempatkan dan menyimpan data spasial dengan menggunakan titik-titik, garis-garis atau kurva, atau poligon beserta atribut-atributnya [11]. Dalam merepresentasikan data spasial menggunakan model data vektor, didefinisikan oleh sistem koordinat kortesian dua dimensi yaitu sumbu x dan sumbu y. Pada model data vektor, garis atau kurva disimpan dalam bentuk sekumpulan titik-titik terurut dihubungkan dihubungkan. Sedangkan luasan atau poligon disimpan sebagai sekumpulan titik-titik terurut tetapi nilai titik awal dan titik akhir poligon memiliki nilai koordinat yang sama[13].

\subsection{Analisa Spatial}

Kemampuan menganalisis sistem seperti analisa statistik dan overlay merupakan karakteristik utama Sistem Informasi Geografis. Analisa dengan system tersebut sering digunakan dengan istilah analisa spasial, dengan menambahkan dimensi 'ruang (space)' atau geografi. Dalam analisis spasial ini, penggambaran attribut-attribut pada bermacam fenomena seperti umur, tipe jalan, dan sebagainya, yang secara bersama dengan informasi lokasi tinggal atau lokasi alamat berupa jalan [14]. Dengan menggunakan system overlay dua peta akan menghasilkan peta baru hasil analisis [14] .

\section{METODE PENELITIAN}

Metode yang digunakan dalam penelitian ini adalah Analisis spasial, merupakan kumpulan - kumpulan dari teknik yang dapat digunakan untuk melakukan pengolahan data SIG. Hasil dari analisis data spasial sangat bergantung dari lokasi atau tempat di mana objek sedang dianalisis. Selain itu, analisis spasial juga bisa diartikan sebagai teknik - teknik yang dapat digunakan untuk meneliti dan juga mengeksplorasi dari dari sudut pandang keruangan. Semua teknik ataupun pendekatan perhitungan secara matematis yang berhubungan dengan data keruangan atau spasial dilakukan dengan menggunakan fungsi analisis spasial[8].

Gambar 1 merupakan Pendekatan dalam model spasial yang digunakan pada pemetaan jaringan irigasi dan embung di Lombok Tengah.

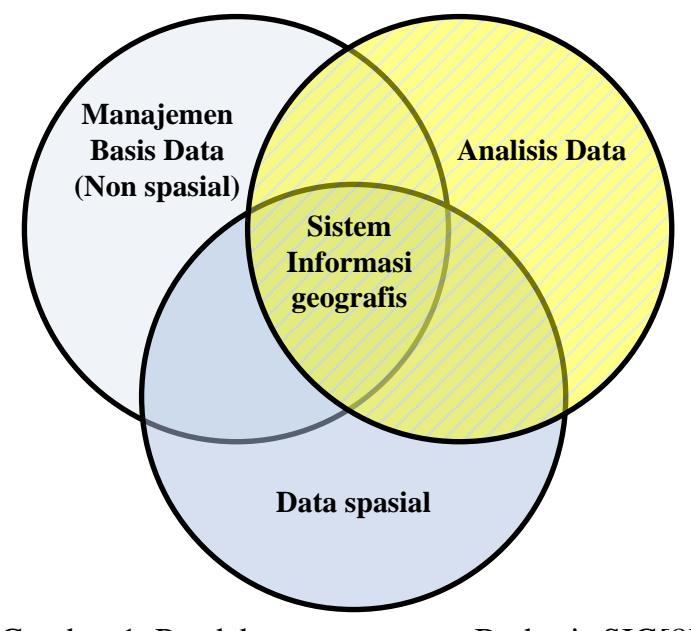

Gambar 1. Pendekatan pemetaan Berbasis SIG[8]

Pengembangan sistem informasi berbasis SIG, pada dasarnya terdiri atas tiga pendekatan:

\subsection{Manajemen Basis Data non Spasial}

Manajemen basis data menggunakan pendekatan dengan melakukan identifikasi, dan klasifikasi data, dengan merancang basis data melalui analisis data dengan cara inventarisasi data dan standarisasi data, penyusunan model konsep data (diagram arus data), relasi antara data, dan penyusunan kamus data[8].

\subsection{Sistem Informasi Geografis (SIG)}

Kawasan irigasi dan embung adalah daerah yang menjadi object spasial dari penelitian ini di wilayah Lombok Tengah. Untuk mengetahui daerah irigasi dan embung dilakukan dengan operasi buffer untuk mengetahui dan menganalisa daerah yang dilalui irigasi.SIG yang dianggap sebagai alat yang membantu pengguna dalam mendapatkan informasi yang lebih lengkap, mencakup penggambaran secara keruangan sehingga dapat dengan mudah memperoleh maupun menganlisa informasi lebih lanjut. Prosedur Kerja dari Sistem Informasi Geografis dapat dilihat pada gambar 2 berikut [15] 


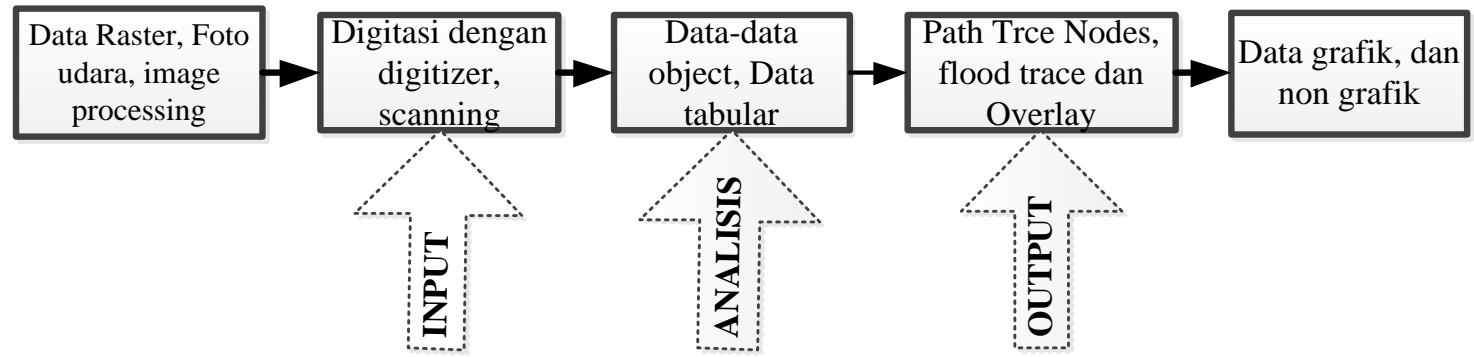

Gambar 2. Prosedur kerja SIG

\subsection{Data Spasial}

Yang merupakan masukan data spasial adalah sumber untuk membuat peta data geografisnya, yang apabila peta yang dibuat menghasilkan peta digital yang valid. Untuk menghasilkan peta digital, memerlukan proses digitasi dengan cara digitasi langsung menggunakan alat input data digitizer yang bisa langsung menjadi peta dijitalnya. Cara lain adalah dengan cara scanning peta kartografi, foto udara, atau satelit yang kemudian dilakukan proses dijitasi dengan cara diimport ke perangkat lunak yang bisa mentransformasikan peta hasil scanning ke peta dijital seperti Autocad atau Autocad Map atau MapInfo. [16]. Berikut sumber layer peta spasial sebagai input data spasial irigasi dan embung di Kabupaten Lombok Tengah.

1. Layer Batas Wilayah Kabupaten Lombok Tengah

2. Layer Struktur Tanah

3. Layer Jalan

4. Layer irigasi

5. Layer Fungsi Kawasan kota, pertanian

6. Layer Penggunaan Tanah

PemerIntah Kabupaten Lombok Tengah

Dinas Pekerjaan Umum Bidang Pengairan

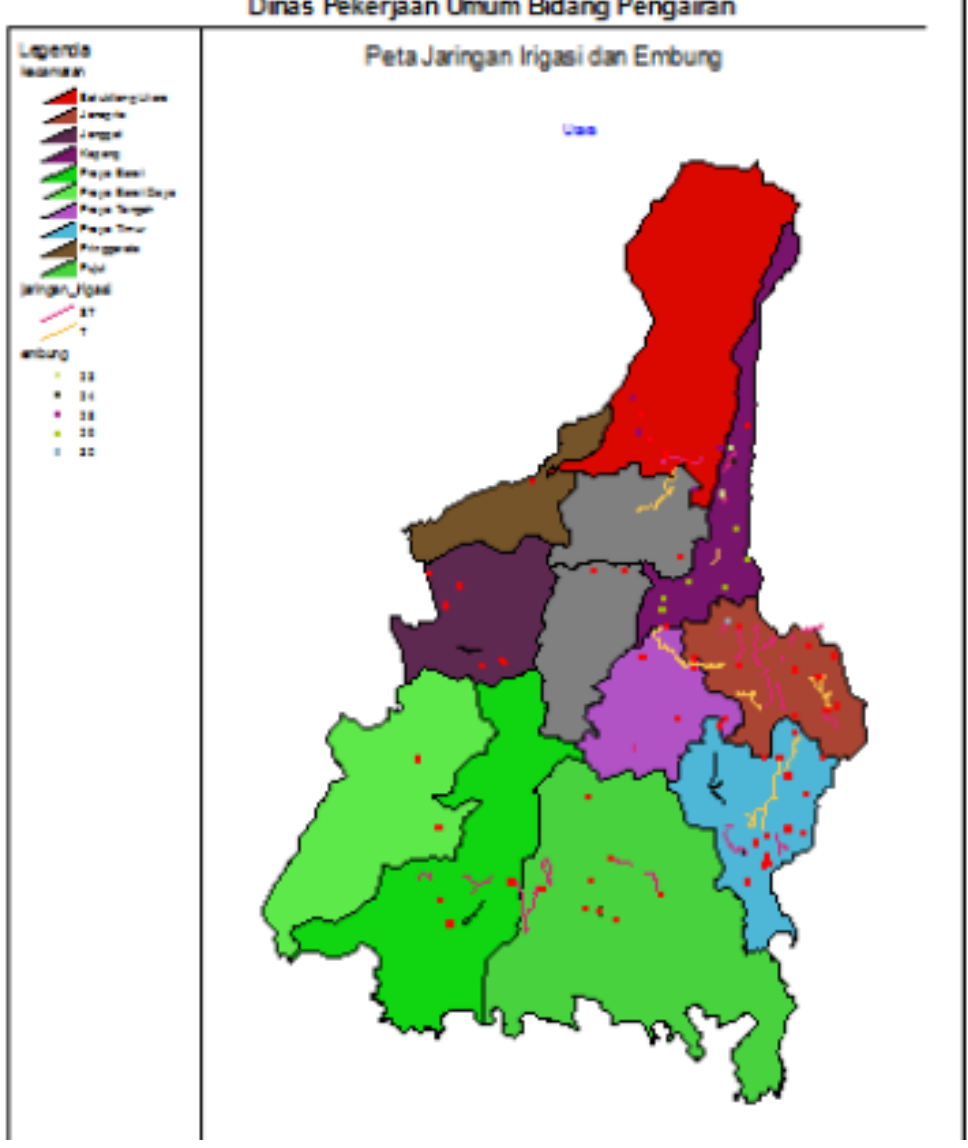

Gambar 3. Peta lokasi 


\subsection{Analisis Data}

Dalam penelitian ini, Metode analisis yang digunakan adalah analisis kuantitatif, yaitu sebuah metode dengan mengkaji fenomena perubahan ruang pada setiap analisis yang dilakukan. Metode ini menggunakan prosedur yang terukur dan sistematis yang didukung oleh data-data numerik. Metode analisis spasial pada penelitian ini, yaitu metoda penelitian yang menjadikan peta, sebagai model yang merepresentasikan dunia nyata yang diwakilinya, sebagai suatu media analisis guna mendapatkan hasil-hasil analisis yang memiliki atribut keruangan. Pada tahap analisis spasial ini memberikan peranan penting untuk dalam memperoleh gambaran keterkaitan di dalam permasalahan wilayah studi [17].

Analisis kondisi dan fungsi jaringan irigasi dilakukan untuk memperoleh penilaian kondisi dan fungsi berdasarkan penilaian parameter tertimbang terhadap bobot setiap parameter yaitu: kondisi dan box tersier dan kuarter, kondisi dan fungsi saluran tersier dan primer. Indicator kondisi dan fungsi jaringan irigasi ditentukan parameter sebagai berikut [18]:

1. Kondisi dan fungsi box tersier dan kuarter =

Jumlah box tersier dan kuarter yang berfungsi (bh)

Jumlah box tersier dan kuarter yang ada

2. Kondisi dan fungsi saluran tersier dan kuarter $=$

Panjang saluran tersier dan kuarter yang berfungsi (m)

3. Kerapatan saluran $=$

Panjang saluran tersier dan kuarter yang ada

Panjang saluran tersier dan kuarter yang ada (m)

Panjang saluran tersier dan kuarter yang ideal

Penilaian terhadap indikator kondisi dan fungsi jaringan irigasi tersier dilakukan dengan cara pemberian bobot penilaian untuk masing-masing parameter disajikan pada Tabel 1.

Tabel 1. Kriteria penilaian parameter dari indikator kondisi jaringan irigasi tersier[18]

\begin{tabular}{|c|c|c|c|c|}
\hline No & Parameter & $\begin{array}{l}\text { Nilai } \\
\text { Parameter }\end{array}$ & $\begin{array}{l}\text { Bobot } \\
(\%)\end{array}$ & $\begin{array}{l}\text { NilaiParameter } \\
\text { Tertimbang }\end{array}$ \\
\hline 1 & $\begin{array}{l}\text { Kondisi dan fungsi boks tersier dan } \\
\text { kuarter }\end{array}$ & & 50 & \\
\hline 2 & $\begin{array}{l}\text { Kondisi dan fungsi saluran tersier dan } \\
\text { kuarter }\end{array}$ & & 30 & \\
\hline 3 & Kerapatan saluran & & 20 & \\
\hline & Jumlah & & 100 & \\
\hline
\end{tabular}

Standar bobot nilai dan nilai pendekatan kuantitatif untuk masing-masing bobot parameter dan indikator adalah :

1. $80<$ Nilai $\leq 100$, adalah Sangat Baik

2. $60<$ Nilai $\leq 80$, adalah Baik

3. $40<$ Nilai $\leq 60$, adalah Kurang

4. Nilai $\leq 40$, adalah Sangat Kurang

\section{HASIL DAN ANALISIS}

Hasil dari perancangan model spasial untuk pemetaan irigasi dan embung dapat dilihat dari tampilan menu utama seperti pada gambar 4 berikut, dengan beberapa menu seperti: Manipulasi data, yang berfungsi untuk menampilkan jendela manipulasi data non-spasial jaringan irigasi, embung, dan kecamatan. Pengguna yang memiliki level user hanya dapat memanipulasi data jaringan irigasi, embung, dan kecamatan. Pada jendela manipulasi data, pengguna dapat melakukan penambahan, perubahan dan penghapusan terhadap data tabular yang ada. Pada jendela manipulasi data memiliki fasilitas pencarian sesuai dengan data yang sedang diakses. Disampin menu manipulasi data ada juga menu cetak laporan, yang berfungsi untuk memfasilitasi mencetak data tabular pada jaringan irigasi dan embung. Sementara menu Tampilan, berfungsi untuk menampilkan nama kecamatan, nama daerah irigasi dan nama embung yang ada pada data spasial, menampilkan nama jaringan irigasi, embung, dan kecamatan sesuai dengan posisi kursor, serta menampilkan diagram untuk persentase kerusakan jaringan irigasi. 


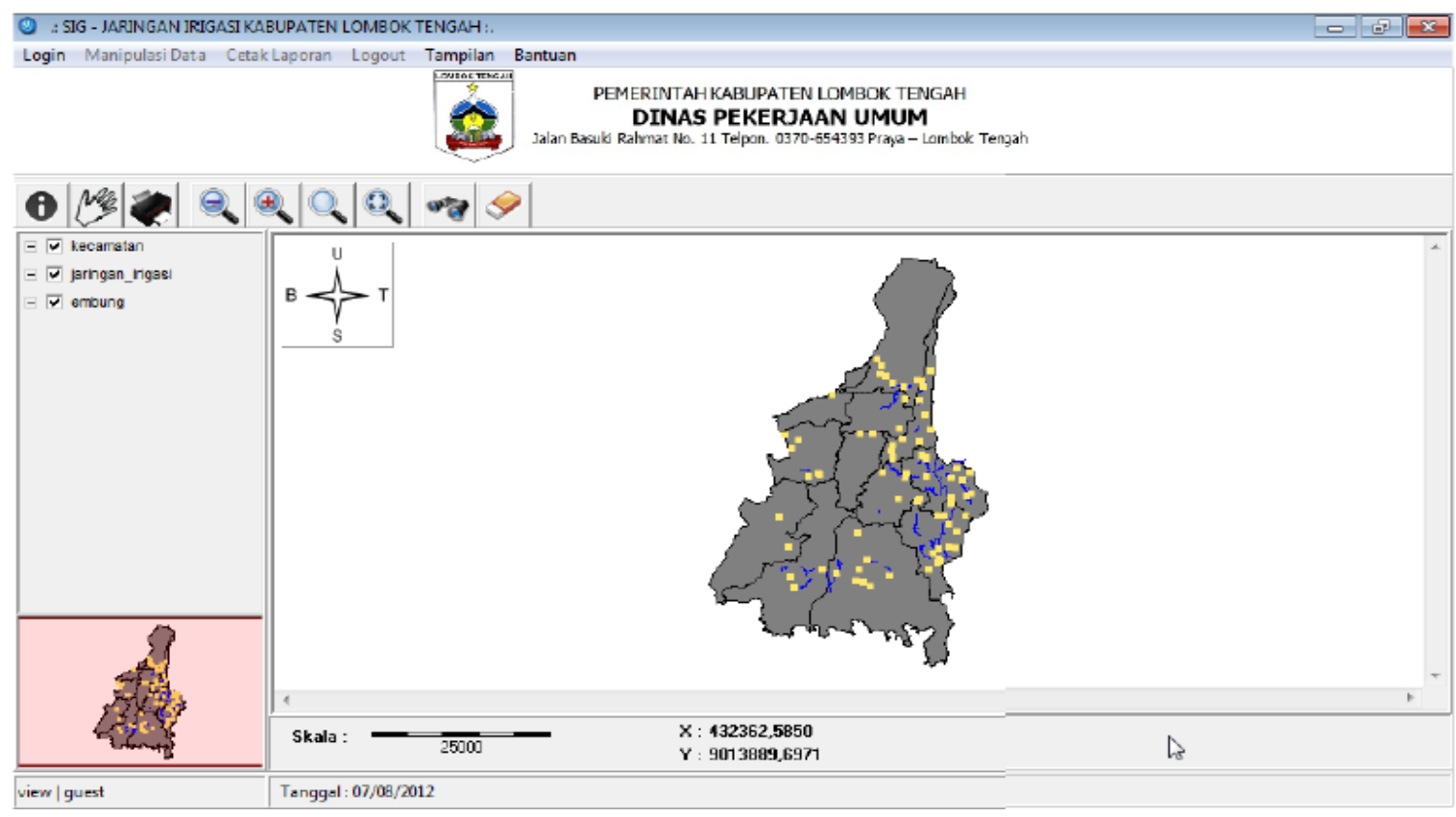

Gambar 4. Tampilan data spasial jaringan irigasi dan embung

Selain itu terdapat juga menu Toolbar yang memudahkan user untuk menuju ke sub menu berikutnya hanya dengan memilih symbol-simbol yang terdapat pada tampilan berupa gambar atau symbol seperti pada gambar 4 . Beberapa menu toolbar antara lain, Informasi, berfungsi untuk mengetahui informasi yang ada pada data spasial yang dipilih. Ada juga zoom yang digunakan untuk memperbesar dan mempekecil ukuran peta yang tampil pada aplikasi dengan toolbar Normal untuk mengembalikan ukuran dan posisi peta seperti sebelum pengguna melakukan perbesar peta, perkecil peta, zoom, atau menggeser peta. Selain itu menu toolbar yang penting untuk manipulasi peta adalah pencarian data spasial adan nonspasial, dimana Toolbar pencarian data non-spasial berfungsi untuk memanggil jendela pencarian yang digunakan untuk mencari data nonspasial atau tabular yang ada pada peta. Skala Peta, berfungsi untuk menampilkan skala peta yang ada pada aplikasi, sementara Legenda toolbar berfungsi untuk menampilkan nama data spasial yang ada pada aplikasi dan dapat digunakan untuk mengaktifkan atau menonaktifkan data spasial yang ingin ditampilkan pada aplikasi dan menampilkan simbol yang digunakan pada peta. Koordinat $\mathrm{x}$ dan $\mathrm{y}$, menunjukan koordinat $\mathrm{x}$ dan y yang ada pada data spasial Peta Kecil, yang berfungsi untuk mememantau posisi peta yang tampil pada aplikasi.

Sementara algoritma untuk menampilkan menu utama dibuat dengan menggunakan diagram alir sebagai dasar pembuatan coding atau program dengan bahasa pemrograman Delphi. Pada algortma tampilan menu utama terdapat banyak kondisi sebagai akibat dari banyaknya pilihan menu yang bisa dilakukan user, sehinga diagram alir yang atau flochrat pada gambar 5 menunjukan banyaknya kondisi atau alternative pilihan dengan symbol keputusan. Penjelasan berikut menunjukan beberapa pilihan menu seperti, login, tampilan, bantuan, informasi, geser, perbesar peta, perkecil peta, zoom, normal, pencarian, dan hapus seleksi peta.

Memilih kondisi fasilitas login, jika berhasil maka dapat menggunakan fasilitas manipulasi data dan cetak laporan, sehingga selanjutnya pengguna dapat menggunakan fasilitas manipulasi data, untuk menampilkan jendela manipulasi data untuk data jaringan irigasi, embung, kecamatan, dan pegawai. Kondisi lain adalah fasilitas cetak laporan mempunyai dua pilihan, yaitu cetak laporan data jaringan irigasi dan cetak laporan data embung. Jika pengguna menggunakan fasilitas cetak laporan jaringan irigasi, maka aplikasi akan menampilkan jendela yang berisi laporan jaringan irigasi. Tapi jika pengguna menggunakan fasilitas cetak laporan embung, maka aplikasi akan menampilkan jendela yang berisi data embung. Jika pengguna memilih fasilitas informasi, maka pengguna akan mendapatkan informasi dari data spasial yang dipilih. Sementara memilih fasilitas geser, maka pengguna dapat menggeser peta untuk melihat bagian peta yang tidak tampak pada aplikasi. Kondisi memilih fasilitas perbesar atau memperkecil peta (zoom), untuk memperbesar dan memperkecil ukuran peta yang tampil pada aplikasi.

\subsection{Manipulasi data Irigasi}

Data-data jaringan irigasi digunakan sebagai data referensi utama dalam pembangunan model spasial ini. Data-data objek jaringan irigasi didapatkan dari hasil ekstraksi pada berkas daftar daerah irigasi kabupaten Lombok Tengah dan jaringan_irigasi.shp.

Pada jendela manipulasi data terdapat kolom tingkat kerusakan jaringan. Nilai tingkat kerusakan jaringan ditentukan oleh luas areal irigasi, jumlah persentasi kerusakan jaringan irigasi dan panjang total saluran irigasi. Jumlah persentasi kerusakan 
irigasi didapatkan dari panjang saluran induk yang rusak ditambag dengan panjang saluran sekunder yang rusak, kemudian dibagi dengan total panjang saluran, lalu dikali 100\%. gambar 5 adalah data spasial kerusakan jaringan irigasi

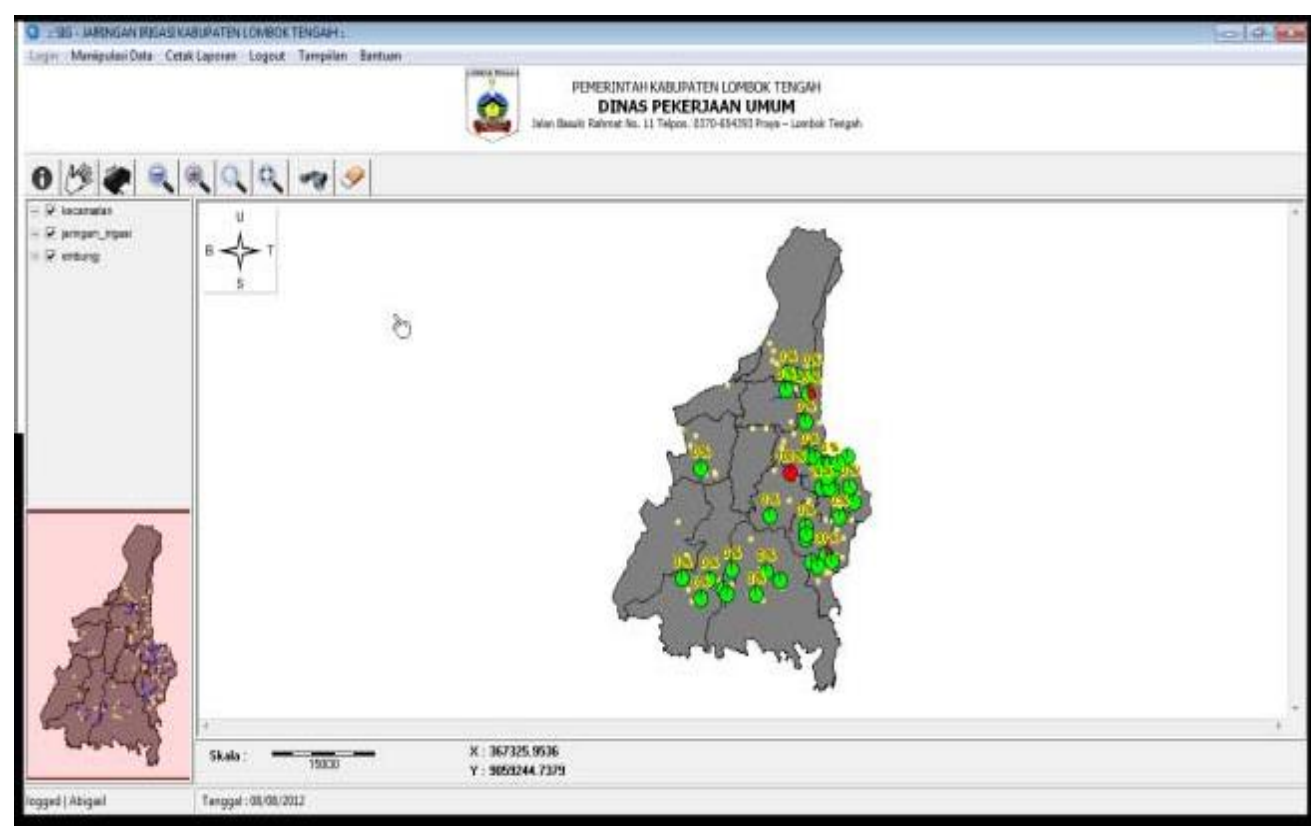

Gambar 5. tampilan sata spasial kerusakan jringan irigasi

Sedangkan identifikasi kebutuhan data untuk objek jaringan irigasi pada tabel 2.

Tabel 2. Atribut spasial jaringan irigasi

\begin{tabular}{|c|c|c|}
\hline \multicolumn{2}{|c|}{ No. Nama Kolom } & Keterangan \\
\hline 1 & No & Nomor urut daerah irigasi dan dapat dijadikan data pembeda \\
\hline 2 & Daerah irigasi & Nama daerah irigasi \\
\hline 3 & Foto & Foto jaringan irigasi \\
\hline 4 & Tingkat Jaringan & $\begin{array}{lll}\text { jaringan } & \text { irigasi } \quad \text { teknis(T); Semiteknis(ST); }\end{array}$ \\
\hline 5 & Dibangun Tahun & Tahun daerah irigasi dibangun \\
\hline 6 & Jumlah Mata Air & Jumlah mata air yang ada di daerah irigasi \\
\hline 7 & Embung Rakyat & Jumlah embung yang ada pada derah irigasi \\
\hline \multirow[t]{3}{*}{8} & Panjang Saluran & \\
\hline & Induk & Panjang saluran induk jaringan irigasi dengan satuan meter (m) \\
\hline & Sekunder & $\begin{array}{llll}\text { saluran } & \text { sekunder } & \text { jaringan } & \text { irigasi }(m)\end{array}$ \\
\hline \multirow[t]{3}{*}{9} & Luas Areal & \\
\hline & Potensial & Luas area daerah potensial dengan satuan hektar(ha) \\
\hline & Irigasi & Luas daerah irigasi dengan satuan hektar (ha) \\
\hline \multirow[t]{3}{*}{10} & Kondisi jaringan & \\
\hline & Tingkat Kerusakan & Tingkat kerusakan jaringan irigasi \\
\hline & $\begin{array}{l}\text { Persentase Kerusakan } \\
\text { Kondisi Kerusakan }\end{array}$ & Persentase kerusakan daerah jaringan irigasi \\
\hline \multirow{2}{*}{11} & Induk & Kondisi kerusakan saluran induk \\
\hline & Sekunder & Kondisi kerusakan saluran sekunder jaringan irigasi (m) \\
\hline
\end{tabular}

Data-data spasial yang terdapat pada tabel data spasial diatas menggambarkan nama-nama atribut spasial yang digunakan dalam pembuatan model aplikasi spasial irigasi dengan penjelasan atau keterangan atribut spasialnya. Ada beberapa contoh atribut spasial seperti nama daerah irigasi, panjang saluran, luas areal, kondisi jaringan, merupakan atribut-atribut spasial yang digunakan untuk manipulasi model spasial. Gambar 6 berikut adalah bentuk tampilan aplikasi menu manipulasi data jaringan 
irigasi untuk pencarian data jaringan irigasi. Dimana untuk mencari jaringan irigasi pengguna dapat menginputkan daerah irigasi, tahun dibangun, luas area, panjang saluran dan kondisi kerusakan.

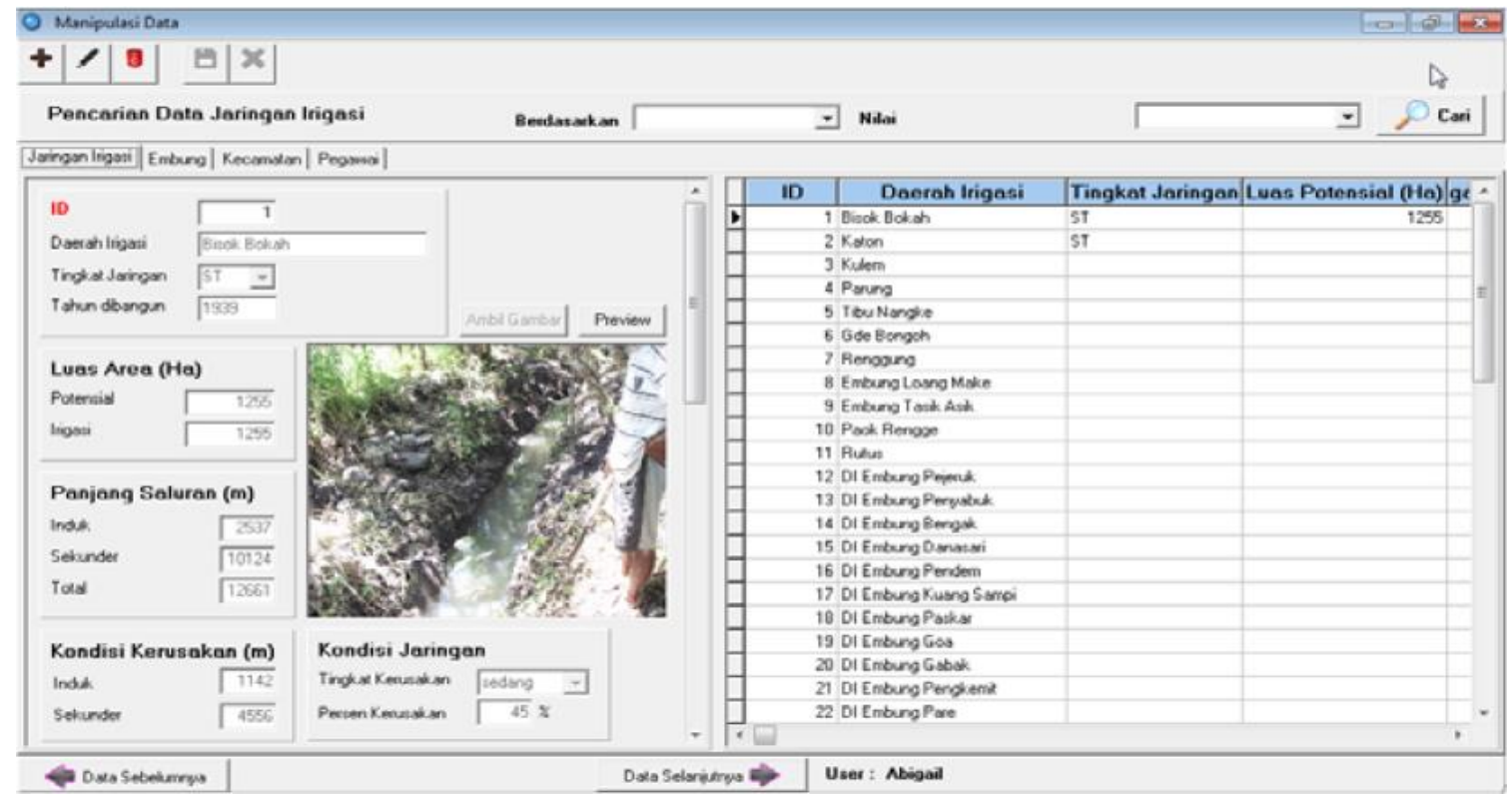

Gambar 6. Tampilan menu manipulasi data jaringan irigasi

\subsection{Manipulasi data Embung}

Selain data spasial irigasi, terdapat juga objek data spasial embung, didapatkan dari hasil ekstraksi pada berkas embung.shp seperti pada tabel 3. Beberapa atribut spasial untuk objek embung adalah kode embung, nama embung, area embung yang menggambarkan luas embung, lokasi administrasi (kecamatan) dan gambar skema embung.

Tabel 3. Atribut spasial embung

\begin{tabular}{lll}
\hline No & Nama Kolom & Keterangan \\
\hline 1 & id & kode embung \\
2 & nama-embung & nama embung \\
3 & area & Area yang dialiri embung dengan satuan \\
& & hektar (ha) \\
4 & kecamatan & Lokasi kecamatan embung \\
5 & skema & Gambar skema embung \\
\hline
\end{tabular}

Prinsip kerja yang sama seperti irigasi digunakan untuk manipulasi data embung, berdasarkan data spasial embuh.shp dengan atribut seperti pada tabel 3. Untuk data spasial embung yang ditampilkan dilayar pada gambar 7, berikut menampilna sebaran data embung di wilayah Lombok tengah.

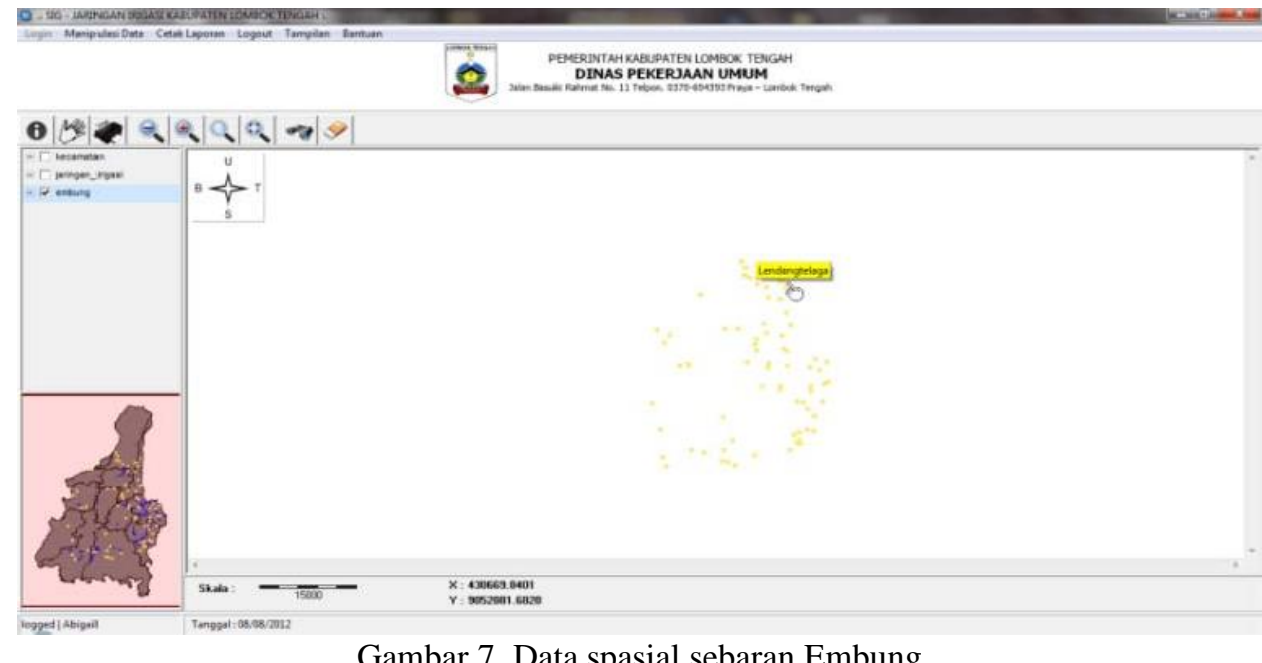

Gambar 7. Data spasial sebaran Embung 
Hasil manipulasi spasial dari data embung.shp beserta atributnya dapat dilihat pada gambar 8 berikut berupa menu manipulasi data jaringan embung untuk pencarian data embung. Untuk melakukan pencarian data embung memerlukan input seperti, kode embung, nama embung dan area maka akan muncul gambar embung disertai dengan atribut sebagai identitas embung.

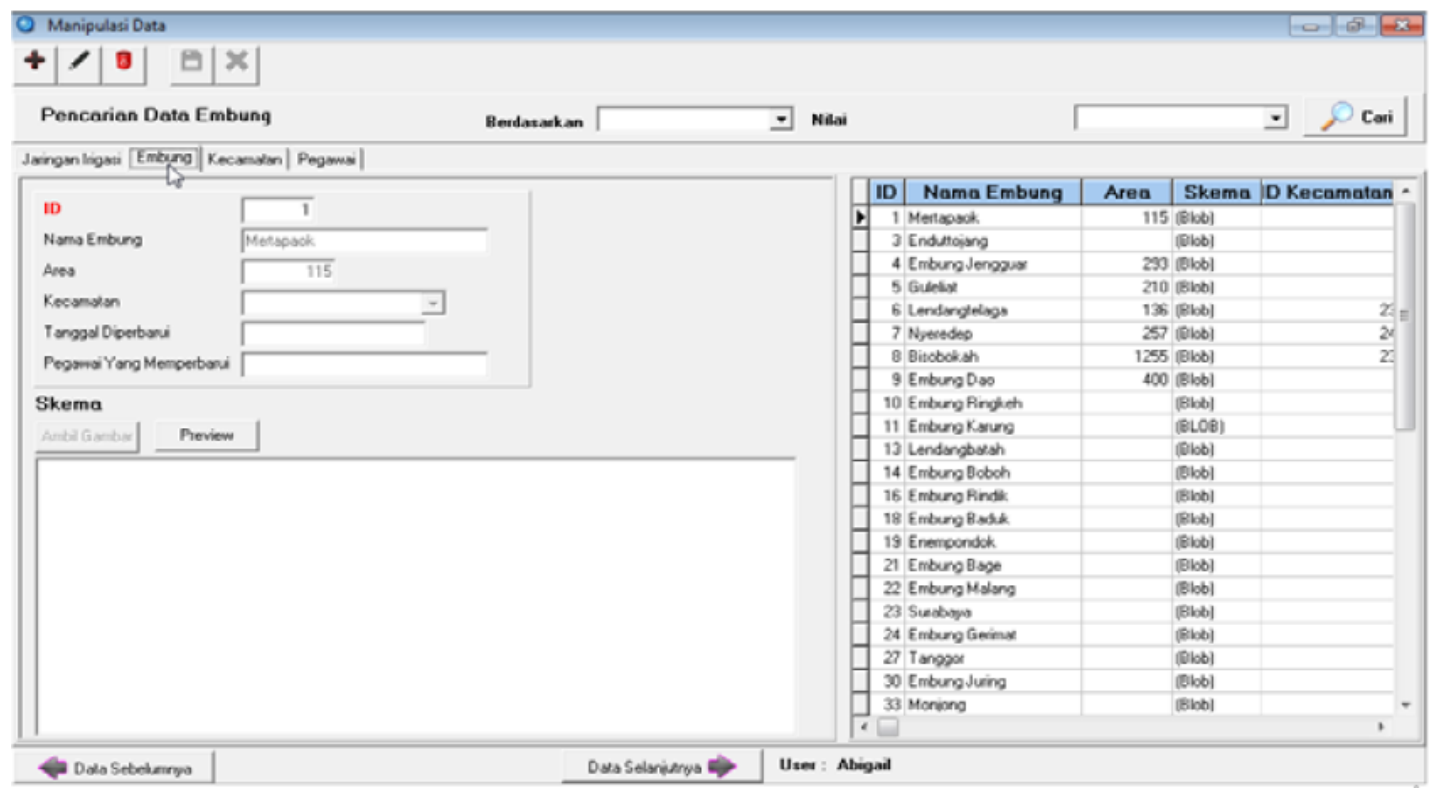

Gambar 8. Tampilan menu manipulasi data jaringan embung

\section{KESIMPULAN}

Dari perancangan perangkat lunak data spasial untuk pemetaan irigasi dan embung, menghasilkan Manipulasi data spasial, yang menampilkan jendela manipulasi data non-spasial jaringan irigasi, dan embung. Peta yang ditampilkan pada halaman aplikasi merupakan peta hasil operasi spasial dan pengguna yang memiliki level user tertentu saja yang dapat memanipulasi data jaringan irigasi, embung tersebut. Pada jendela manipulasi data pengguna dapat melakukan penambahan, perubahan dan penghapusan terhadap data tabular yang ada dan memiliki fasilitas pencarian sesuai dengan data yang sedang diakses. Akses manipulasi spasial dan non spasial ini memudahkan admin dalam menentukan lokasi secara spasial. Pada layar aplikasi terlihat bahwa untuk mencari dan memanipulasi data spasial dapat dilakukan dengan memilih menu yang telah disediakan dengan menginputkan beberapa atribut sebagai kata kunci untuk pencarian data. Berdasarkan hasil uji coba model aplikasi ini dapat di jalankan dan mudah untuk digunakan oleh pengguna karena dilengkapi dengn system navigasi yang baik. Sebagai saran untuk kelanjutan dari system ini adalah untuk menggunakan aplikasi android yang bisa diakses oleh user melalui mobile dan berbagai platform.

\section{REFERENSI}

[1] A. G. Pradipta, M. Murtiningrum, N. W. D. Febriyan, F. A. Rizqi, and N. Ngadisih, "Prioritas Pengembangan dan Pengelolaan Jaringan Irigasi Tersier di Daerah Istimewa Yogyakarta Menggunakan Multiple Attribute Decision Making,” Jurnal Irigasi, vol. 15, no. 1, pp. 55-69, 2020.

[2] R. Amalia, R. S. B. Waspodo, and B. I. Setiawan, "Rancangan Sistem Irigasi Evaporatif untuk Tanaman Lada," Jurnal Irigasi, vol. 15, no. 1 , pp. $45-54,2020$.

[3] A. H. Indarta and H. Tuasikal, "Rancang Bangun dan Evaluasi Kinerja Irigasi Mikro di Pulau Haruku , Maluku Design and Performance Evaluation of Micro-Irrigation in Haruku Island, Maluku,” vol. 15, no. 1, pp. 31-44, 2020.

[4] M. S. Dangnga, "Dampak Pembangunan Embung Bagi Usaha Tani Padi Sawah Tadah Hujan," Jurnal Galung Tropika, vol. 8, no. 3, pp. 224-234, 2019.

[5] C. J. Wicaksana, A. Y. Muttaqien, and R. R. R. Hadiani, "Pemanfaatan Embung Sambirejo Kabupaten Sragen Sebagai Sarana Pemenuhan Kebutuhan Air Non Irigasi," Jurnal Matriks Teknik Sipil, vol. 6, no. 2, pp. 282-292, 2018.

[6] Hariyanto, “Analisis Penerapan Sistem Irigasi untuk Peningkatan Hasil Pertanian di Kecamatan Cepu Kabupaten Blora,” RiCE: Jurnal Reviews in Civil Engineering, vol. 2, no. 1, pp. 29-34, 2018.

[7] M. Mizir, "Kajian pembangunan Embung irigasi lurah kapecong di kabupaten solok," Jurnal Teknik Sipil ITP, vol. 3, no. 1, pp. 49-59, 2016. 
[8] A. Adil, “Analisa Spasial Pemetaan Lokasi Wisata Agro,” MATRIK : Jurnal Manajemen, Teknik Informatika dan Rekayasa Komputer, vol. 16, no. 1, pp. 1-11, 2016.

[9] K. Yasin and A. Adil, "Implementasi Google Maps API Pemetaan Jalur Evakuasi Bencana Alam di Kabupatem Lombok Utara," MATRIK : Jurnal Manajemen, Teknik Informatika dan Rekayasa Komputer, vol. 19, no. 1, pp. 138-146, 2019.

[10] S. Dewi Handayani, R.Soelistijadi, "Pemanfaatan Analisis Spasial untuk Pengolahan Data Spasial Sistem Informasi Geografi," Jurnal Teknologi Informasi Dinamik, vol. 10, no. 2, pp. 108-116, 2005.

[11] E. Prahasta, “Sistem Informasi Geografis:Konsep-Konsep Dasar (Prespektif Geodesi \& Geomatika),” p. 78, 2009.

[12] R. S. Bivand, E. Pebesma, and V. Gómez-Rubio, Applied Spatial Data Analysis with R: Second Edition. Verlag New York, Amerika Serikat: Springer, 2013.

[13] A. Y. Prawira, K. Wikantika, F. Hadi, and Geodesi, "Analisis Spasial Lahan Kritis di Kota Bandung Utara Menggunakan Open Source Grass,” in Pertemuan Ilmiah Tahunan Mapin XIV Institut Teknologi Sepuluh November Surabaya, 2005, pp. 14-15.

[14] S. P. Nugroho and T. Prayogo, "Penerapan Sig untuk Penyusunan dan Analisis Lahan Kritis Pada Satuan Wilayah Pengelolaan Das Agam Kuantan, Provinsi Sumatera Barat," Jurnal Teknik Lingkungan, vol. 9, no. 2, pp. 130-140, 2008.

[15] G. M. E. Hartoyo, Y. Nugroho, A. Bhirowo, and B. Khalil, Modul Pelatihan ArcGis Analisa Spasial Modul Pelatihan ArcGis. Bogor, Indonesia: Tropenbos International Indonesia Programme, 2010.

[16] A. Puntodewo, S. Dewi, and J. Tarigan, "Pengelolaan Data Geospasial," Sistem Informasi Geografis Untuk Pengelolaan Sumber Daya Alam, pp. 6-48, 2003.

[17] A. Puntodewo, S. Dewi, and J. Tarigan, “Analisa Data Geospasial dan Non-Spasial,” Sistem Informasi Geografis Untuk Pengelolaan Sumber Daya Alam, pp. 49-88, 2003.

[18] Oktavianti, Subari, and E. Yulius, "Pemetaan Jaringan Irigasi Daerah Jawa Barat Berbasis Sistem Informasi Geofrafis (GIS)," Jurnal Benteng, vol. 2, no. 1, pp. 53-65, 2014. 